\title{
EVALUASI IMPLEMANTASI STANDAR PELAYANAN KEFARMASIAN DI APOTEK PERORANGAN DAN WARALABA WILAYAH KOTA YOGYAKARTA TAHUN 2019
}

\section{EVALUATION OF PHARMACEUTICAL SERVICE STANDARD IMPLEMENTATION IN INDIVIDUAL AND FRANCHISE PHARMACY IN YOGYAKARTA CITY REGION 2019}

\author{
Yoga Dwi Saputra ${ }^{1}$, Nabela Febi Choirunnisa ${ }^{1}$, Zha Zha Arisca ${ }^{1}$ \\ ${ }^{1}$ Program Studi Diploma III Farmasi Akademi Farmasi Indonesia Yogyakarta \\ Korespondensi : yogadwisaputra@afi.ac.id
}

\begin{abstract}
ABSTRAK
Kegiatan pelayanan farmasi yang semula berfokus pada pengelolaan obat sebagai komoditi harus diubah menjadi pelayanan yang komprehensif dan bertujuan untuk meningkatkan kualitas hidup pasien termasuk pelayanan kefarmasian di apotek. Semakin banyaknya apotek yang berbentuk waralaba dibandingkan dengan apotek Perorangan membuat persaingan ekonomi dan pelayanan farmasi semakin ketat. Penelitian ini bertujuan untuk melakukan evaluasi implementasi standar pelayanan kefarmasian antara apotek Perorangan dan apotek waralaba.

Jenis penelitian ini adalah observasional pendekatan deskriptif. Pengumpulan data menggunakan kuesioner tentang implementasi standar pelayanan kefarmasian di apotek. Responden pada penelitian ini adalah apoteker yang berpraktek di apotek dengan jumlah sebanyak 28 orang yang terbagi menjadi 21 orang apoteker apotek Perorangan dan 7 apoteker apotek waralaba. Analisa data dilakukan dengan cara menghitung jumlah setiap jawaban responden, kemudian dibuat peresentase dan data disajikan dalam bentuk tabel perbandingan dan evaluasi implementasi Permenkes RI No. 73 tahun 2016, dan di uji dengan menggunakan SPSS tipe 16 menggunakan uji Independent Sample t-Test dan uji Mann Whitney, serta dideskripsikan dalam bentuk narasi.

Hasil Penelitian ini apotek Peroranganan dan apotek waralaba di Kota Yogyakarta dalam mengimplementasikan Standar Pelayanan Kefarmasian telah sesuai dengan peraturan Menteri Kesehatan RI Nomor 73 Tahun 2016 tentang Standar Pelayanan Kefarmasian Di Apotek. Persentase yang diperoleh apotek Perorangan sebesar 76,34 \% dan apotek waralaba sebesar 82,97\%. Dalam implementasi Standar Pelayanan Kefarmasian tidak terdapat perbedaan yang signifikan antara pelayanan kefarmasian di apotek Peroranganan dan waralaba di wilayah Kota Yogyakarta terbukti dari nilai sig. (2-tailed) $0.103>0,05$.
\end{abstract}

Kata Kunci : Pegelolaan Obat, Apotek, Perorangan, Waralaba, Kota Yogyakarta

\begin{abstract}
Pharmaceutical service activities that initially focused on drug management as a commodity must be converted into a comprehensive service and aims to improve the quality of life of patients including pharmacy services at the pharmacy. The increasing number of pharmacies in the form of franchises compared to individual pharmacies makes economic competition and pharmaceutical services tighter. This study aims to evaluate the implementation of pharmaceutical service standards between individual pharmacies and franchise pharmacies.

This type of research is an observational descriptive approach. Data collection using a questionnaire about the implementation of pharmaceutical service standards at the pharmacy. Respondents in this study were pharmacists who practiced pharmacies with a total of 28 people divided into 21 pharmacists per pharmacy and 7 pharmacist pharmacists. Data analysis is done by calculating the amount of each respondent's answer, then made a percentage and the data is presented in the form of a comparison table and evaluation of the implementation of the Republic of Indonesia Ministerial Regulation No. 73 of 2016, and tested using SPSS type 16 using the Independent Sample t-Test and Mann Whitney test, and described in narrative form.
\end{abstract}


The results of this study are individual pharmacies and franchise pharmacies in the city of Yogyakarta in implementing Pharmaceutical Service Standards in accordance with the regulation of the Minister of Health of the Republic of Indonesia No. 73 of 2016 concerning Pharmaceutical Services Standards in Pharmacies. Percentage obtained pharmacies per person by $76.34 \%$ and franchise pharmacies by $82.97 \%$. In the implementation of Pharmaceutical Services Standards there is no significant difference between pharmaceutical services at individual pharmacies and franchises in the Yogyakarta City area as evidenced by the value of sig. (2-tailed) $0.103>0.05$.

Keywords: Drug Management, Pharmacy, Individual, Franchise, Yogyakarta City

\section{PENDAHULUAN}

Sejalan dengan perkembangan ilmu pengetahuan dan teknologi di bidang kefarmasian telah terjadi pergeseran orientasi Pelayanan Kefarmasian dari pengelolaan obat sebagai komoditi kepada pelayanan yang komprehensif (pharmaceutical care) dalam pengertian tidak saja sebagai pengelola obat namun dalam pengertian yang lebih luas mencakup pelaksanaan pemberian informasi untuk mendukung penggunaan obat yang benar dan rasional, monitoring penggunaan obat untuk mengetahui tujuan akhir serta kemungkinan terjadinya kesalahan pengobatan (medication error) (PP 51, 2009). Kesembuhan pasien sebesar 25\% diharapkan diperoleh dari kenyamanan serta baiknya pelayanan apotek, sedangkan $75 \%$ berasal dari obat yang digunakan pasien (Handayani dkk, 2009). Pemerintah menetapkan regulasi untuk mengatur pelaksanaan standar pelayanan kefarmasian dari Apotek yaitu, salah satunya Peraturan Menteri Kesehatan Republik Indonesia Nomor 73 Tahun 2016 tentang Standar Pelayanan Kefarmasian di Apotek. Standar Pelayanan Kefarmasian merupakan tolok ukur yang dipergunakan sebagai pedoman bagi tenaga kefarmasian dalam menyelenggarakan pelayanan kefarmasian (Kemenkes RI, 2016).

Apotek merupakan sarana pelayanan kefarmasian tempat dilakukan praktek kefarmasian oleh apoteker (Kemenkes RI, 2017). Sedangkan Apotek Waralaba merupakan usaha perapotekan yang dikelola oleh suatu perusahaan yang memiliki cabang atau franchis (Galih, 2007). Semakin banyaknya apotek yang berbentuk waralaba membuat persaingan ekonomi dan pelayanan farmasi semakin ketat. Apotek waralaba memiliki standarisasi pelayanan yang berbeda dengan apotek perorangan, kekuatan merek yang berciri khas, ketersediaan produk atau obat yang cukup bervariasi, dan mudah diakses dari berbagai arah lalulintas (Ikun, 2002). Bentuk fisik dan warna apotek waralaba yang menarik serta fasilitas yang lengkap seperti AC, air disepenser, ruangannya tertutup dan bersih, obat-obatan dan barang yang di jual cukup lengkap, pelayannanya cukup memuaskan, buka 24 jam dan disediakan praktik dokter dengan waktu tertentu membuat masyarakat memilih apotek waralaba dari pada apotek Perorangan yang bentuk fisiknya masih sangatlah sederhana (Koto, 2012).

Kota Yogyakarta berkedudukan sebagai ibukota Propinsi DIY dan merupakan satu-satunya daerah tingkat II yang berstatus kota di samping 4 daerah tingkat II lainnya yang berstatus kabupaten (Dinkes Kota Yogyakarta, 2015). Jumlah apotek di Kota Yogyakarta menurut pengurus cabang IAI Kota Yogyakarta pada tahun 2018 sebanyak 138 apotek yang terdiri dari 32 apotek waralaba dan 106 apotek perorangan. Penelitian sebelumnya dilakukan di Kabupaten Sleman, secara keseluruhan sudah memenuhi implementasi standar pelayanan kefarmasian di apotek, namun masih banyak kewajiban apoteker dalam setiap indikator pelaksanaan pelayanan kefarmasian yang belum sepenuhnya dilakukan dengan optimal. Hasil evaluasi implementasi standar pelayanan kefarmasian oleh apoteker di apotek kabupaten Sleman yaitu 65,71\% berkategori baik, 31,43\% berkategori cukup, dan hanya 2,86\% berkategori kurang (Istiqomah, 2012). Penelitian ini dilakukan untuk mengetahui implementasi standar pelayanan kefarmasian di apotek Perorangan dan waralaba kota Yogyakarta dan untuk mengetahui perbedaan pada implementasi standar pelayanan kefarmasian di apotek Perorangan dan waralaba kota Yogyakarta. 


\section{METODOLOGI}

\section{Sampel}

Sampel pada penelitian ini dihitung dari $20 \%$ populasi, yaitu seluruh apotek di Kota Yogyakarta yang berjumlah 138 apotek yang terdiri dari 32 apotek waralaba dan 106 apotek Perorangan (Arikunto, 2002). Teknik sampling yang digunakan adalah simple random sampling, Dari 138 apotek diperoleh sampel sebanyak 28 apotek yang dibagi menjadi 7 apotek waralaba dan 21 apotek Perorangan berdasarkan perbandingan jumlah apotek waralaba dan perorangan. Responden pada penelitian ini adalah apoteker di apotek waralaba dan perorangan yang berpraktek secara langsung di apotek.

\section{Instrumen}

Penelitian ini menggunakan kuesioner dari penelitian Saudari Monica Arum Sukmajati tentang implementasi standar pelayanan kefarmasian di apotek yang telah dimodifikasi dengan pilihan jawaban "Ya" dan "Tidak" yang kemudian diisi oleh apoteker di apotek. Kuesioner ini telah dilakukan uji validitas ulang dengan 3 Expert yang ketiganya merupakan apoteker. Content Validity Index (CVI) meliputi 4 skala, yaitu skala 1 (tidak relevan), skala 2 (tidak dapat dikaji relevansi tanpa merevisi item yang bersangkutan), skala 3 (relevan, dibutuhkan sedikit revisi) dan skala 4 (sangat relevan). Suatu kuesioner dinyatakan valid apabila kuesioner memperoleh nilai $\geq 0,8$ (Polit dan Beck, 2008).

Rumus Validitas :

\section{$\mathrm{V}=$ Nilai $\left(\sum \mathrm{s}\right) /((\mathrm{Jumlah}$ Expert $\mathrm{x}$ (Nilai tertinggi-Nilai terendah))}

Berdasarkan perhitungan nilai validitas pada uji CVI dinyatakan kuesioner tersebut valid dikarenakan skor uji CVI adalah 0,95.

\section{Jalannya Penelitian}

Penelitian ini diawali dengan membuat kuesioner dan melakukan validasi kuesioner, setelah kuesioner valid kemudian dilanjutkan dengan menyerahkan surat permohonan menjadi responden, surat persetujuan menjadi responden dan kuesioner kepada apoteker. Responden yang dipilih pada penelitian ini adalah apoteker di apotek yang berpraktek secara langsung. , kuesioner yang diserahkan kemudian diisi dan dikumpulkan kembali. Analisis data dengan mengelompokan data berdasarkan parameter Permenkes RI nomor 73 Tahun 2016, kemudian menghitung jumlah total tiap prameter jawaban. Data yang terkumpul kemudian dilakukan skoring, jawaban "Ya" bernilai 1 sedangkan jawaban "Tidak" bernilai 0 kemudian dihitung persentasenya dan di uji dengan menggunakan SPSS tipe 16. Data di uji normalitas untuk mengetahui data terdistribusi normal atau tidak. Apabila data terdistribusi normal diuji menggunakan uji Independent Sample t-Test, apabila data tidak terdistribusi normal diuji menggunakan uji Mann Whitney. Untuk mengukur persentase dari jawaban yang didapat dari kuesioner menggunakan skala Guttman dengan menggolongkan menjadi kategori \% kesesuaian (Sugiyono, 2006).

Penelitian ini menggunakan analisis data statistik deskriptif dalam bentuk peresentase dan ditampilkan dalam bentuk tabel dan grafik/diagram, serta dideskripsikan dalam bentuk narasi. Rumus yang digunakan untuk mengukur persentase dari jawaban yang di dapat dari kuesioner menggunakan skala Guttman dengan menggolongkan menjadi kategori \% kesesuaian yaitu : (Sugiyono, 2006)

$$
\text { Persentase }=\frac{\text { Jumlah Skor Penilaian }}{\text { Skor Total }} \times 100 \%
$$

Ket : Implementasi standar pelayanan kefarmasian "Sesuai" $=$ jika skor $=>50 \%$

Implementasi standar pelayanan kefarmasian "Tidak Sesuai" $=$ jika skor $=<50 \%$ 


\section{HASIL DAN PEMBAHASAN}

\section{Deskripsi Data Responden}

Sebagian besar apoteker yang menjadi responden pada penelitiaan ini berusia antara 21 sampai dengan 35 tahun, berjenis kelamin perempuan, memiliki jabatan sebagai Apoteker Pengelola Apotek, memiliki masa kerja 1-5 tahun, hanya memiliki 1 tempat praktek, bekerja 6 hari dalam seminggu dan dalam waktu lebih dari 6 jam perharinya. Karakteristik responden yang diteliti pada penelitian ini dapat dilihat pada Tabel I.

Tabel I. Karakteristik Responden

\begin{tabular}{|c|c|c|c|}
\hline No. & Karakteristik & Jumlah & Persentase (\%) \\
\hline \multirow[t]{4}{*}{1.} & Umur & 28 & 100 \\
\hline & a. 21-35 tahun & 25 & 89,29 \\
\hline & b. $36-50$ tahun & 3 & 10,71 \\
\hline & c. $>50$ tahun & 0 & 0 \\
\hline \multirow[t]{3}{*}{2.} & Jenis Kelamin & 28 & 100 \\
\hline & a. Perempuan & 26 & 92,86 \\
\hline & b. Laki laki & 2 & 7,14 \\
\hline \multirow[t]{4}{*}{3.} & Jenis Kelamin & 28 & 100 \\
\hline & a. Apoteker Pengelola Apotek & 14 & 50 \\
\hline & b. Apoteker Pendamping & 12 & 42,86 \\
\hline & c. Apoteker Pengganti & 2 & 7,14 \\
\hline \multirow[t]{5}{*}{4.} & Pengalaman Kerja & 28 & 100 \\
\hline & a. $<1$ Tahun & 3 & 10,71 \\
\hline & b. 1-5 Tahun & 19 & 67,86 \\
\hline & c. 5-10 Tahun & 5 & 17,86 \\
\hline & d. $>10$ Tahun & 1 & 3,57 \\
\hline \multirow[t]{3}{*}{5.} & Jumlah Tempat Praktek & 28 & 100 \\
\hline & a. Memiliki & 3 & 10,71 \\
\hline & b. Tidak Memiliki & 25 & 89,29 \\
\hline \multirow[t]{4}{*}{6.} & Waktu Bekerja dalam Seminggu & 28 & 100 \\
\hline & a. $<3$ Hari & 0 & 0 \\
\hline & b. 3-5 Hari & 4 & 14,29 \\
\hline & c. 6-7 Hari & 24 & 85,71 \\
\hline \multirow[t]{4}{*}{7.} & Waktu Bekerja dalam Sehari & 28 & 100 \\
\hline & a. $<4$ Jam & 0 & 0 \\
\hline & b. 4-6 Jam & 6 & 21,43 \\
\hline & c. $>6 \mathrm{Jam}$ & 22 & 78,57 \\
\hline
\end{tabular}

\section{Implementasi Standar Pelayanan Kefarmasian di Apotek Peroranganan dan Waralaba}

Hasil yang diperoleh pada penelitian ini menunjukan nilai persentase yang merupakan hasil perolehan persentase implementasi standar pelayanan kefarmasian di apotek Kota Yogyakarta yang digunakan untuk menilai sesuai atau tidaknya pelayanan kefarmasian berdasarkan Peraturan Menteri Kesehatan Nomor 73 Tahun 2016 tentang Standar Pelayanan Kefarmasian di Apotek. Dari hasil penelitian pada implementasi standar pelayanan kefarmasian di apotek Kota Yogyakarta dengan 26 parameter diperoleh hasil persentase rata-rata implementasi standar pelayanan kefarmasian di apotek Peroranganan sebesar 76,34 \% dan diapotek waralaba sebesar 82,97\%. Hasil ini menunjukan bahwa implementasi standar pelayanan kefarmasian di apotek peorangan dan waralaba telah sesuai dengan Peraturan Menteri Kesehatan Nomor 73 Tahun 2016. Namun jika 
dilihat dari setiap parameter implementasi standar pelayanan kefarmasin di apotek masih belum sesuai karena masih terdapat beberapa parameter yang masih dibawah 50\%. Oleh karena itu diharapkan setiap apotek dapat mengimplementasikan standar pelayanan kefarmasian di apotek dengan sebaik mungkin. Hasil persentase Implementasi Standar Pelayanan Kefarmasian di Apotek Peroranganan dan Waralaba dapat dilihat pada tabel II.

Tabel II. Implementasi Standar Pelayanan Kefarmasian di apotek

\begin{tabular}{clcc}
\hline \multirow{2}{*}{ No } & \multicolumn{1}{c}{$\begin{array}{c}\text { Parameter Standar } \\
\text { Pelayanan Kefarmasian }\end{array}$} & \multicolumn{2}{c}{ Persentase (\%) } \\
\cline { 3 - 4 } & & Peroranganan & Waralaba \\
\hline 1. & Perencanaan & 31,92 & 42,85 \\
2. & Pengadaan Jalur Resmi & 100 & 86 \\
3. & Penerimaan & 100 & 100 \\
4. & Dokumentasi & 100 & 100 \\
5. & Penyimpanan khusus & 47,62 & 100 \\
6. & Penyimpanan obat & 85,71 & 71,43 \\
7. & Pemisahan Penyimpanan & 100 & 85,71 \\
8. & Sistem Pengeluaran obat FIFO/FEFO & 90,48 & 100 \\
9. & Pemusnahan Obat & 47,62 & 100 \\
10. & Penyertaan struk penjualan obat & 95,24 & 100 \\
11. & Dokumentasi Penjualan & 90,48 & 100 \\
12. & Pencatatan Penggunaan Narkotika, Psikotropika & 47,62 & 100 \\
13. & Melakukan Pelaporan Obat & 100 & 42,86 \\
14. & Melakukan Pelaporan Narkotika, Psikotropika & 100 & 100 \\
15. & Persyaratan Administatif & 80,95 & 100 \\
16. & Kesesuaiaan Farmasetik & 80,95 & 71,43 \\
17. & Pertimbangan Klinis & 95,24 & 87,14 \\
18. & Konsultasi kepada dokter & 95,24 & 100 \\
19. & Pengecekan Kesesuaiaan obat dan etiket & 80,95 & 71,43 \\
20. & Keterlibatan Apoteker dalam penyerahan obat & 71,43 & 85,71 \\
21. & Pemberian Informasi Obat & 71,43 & 85,71 \\
22. & Konseling Kepada Pasien & 38,10 & 100 \\
23. & Three Prime Question & 38,10 & 42,86 \\
24. & Jam Konseling Berkelanjutan Kepada Pasien Tertentu & 38,10 & 42,86 \\
25. & Tindak Lanjut Terapi melalui komunikasi atau kunjungan & 76,19 & 85,71 \\
26. & Pelayanan Informasi Obat & $\mathbf{7 6 , 3 4}$ & $\mathbf{8 2 , 9 7}$ \\
\hline & & &
\end{tabular}

Pengadaan di apotek harus memperhatikan 4 faktor yaitu pola penyakit, pola konsumsi, kemampuan masyarakat dan budaya masyarakat dalam perencanaan pengadaan obat, sesuai dengan Peraturan Menteri Kesehatan No. 73 Tahun 2016. Pada apotek perorang persentase perencanaan pengadaan obat yang berdasarkan 4 faktor lebih tinggi dari pada apotek waralaba, hal ini mungkin disebabkan prosedur pengadaan pada apotek waralaba dilaksanakan terpusat, sehingga apoteker di apotek waralaba kurang terlibat dalam proses perencanaan. Perencanaan dari apotek perorang yang berdasarkan 4 faktor yaitu sebesar $61,92 \%$ dan apotek waralaba sebesar $42,85 \%$. Pada proses pengadaaan, 21 responden apotek perorangan yang memperoleh obat-obatan melalui jalur resmi $38,10 \%$ selebihnya memperoleh obat-obatan melalui jalur tidak resmi seperti apotek dan toko obat. Pada 7 responden apotek waralaba 85,71\% memperoleh obat-obatan melalui jalur resmi. Sesuai dengan Permenkes Nomor 73 tahun 2016 menyebutkan bahwa "untuk menjamin kualitas pelayanan kefarmasian maka pengadaan harus melalui jalur resmi sesuai ketentuan perundang-undangan". Apotek melakukan kegiatan pembelian hanya ke distributor atau PBF resmi. Pemilihan pemasok 
didasarkan pada beberapa kriteria, antara lain legalitas PBF, kecepatan dalam mengirim barang pesanan, jangka waktu pembayaran, harga yang kompetitif dan untuk obat-obat golongan narkotika hanya dapat dipesan ke PBF yang ditunjuk oleh pemerintah yaitu PBF Kimia Farma (Pharmacy Care, 2016).

Penerimaan obat di apotek dari 28 responden semuanya melakukan kegiatan penerimaan obat sesuai dengan faktur hal ini menunjukan bahwa apotek tersebut telah melakukannya sesuai dengan ketentuan Peraturan Menteri Kesehatan No. 73 Tahun 2016. Proses penerimaan sangat penting karena pada proses inilah kita dapat menyaring barang-barang yang tidak bermutu dan tidak sesuai dengan spesifikasi yang telah ditetapkan mulai dari jenis, jumlah dan kualitas. Spesifikasi dan persyaratan lainnya dari barang yang diterima harus sama dengan yang tercantum dalam faktur/kontrak. Pencatatan atau dokumentasi barang datang pada apotek perorangan dan waralaba sudah dilakukan semua apotek sesuai dengan peraturan Peraturan Menteri Kesehatan No. 73 Tahun 2016. Hal ini menunjukan bahwa semua apoteker di apotek Kota Yogyakarta bertanggung jawab sepenuhnya kulitas obat yang di konsumsi masyarakat, tetapi untuk penyimpanan dengan wadah aslinya sebagian apotek perorangan yaitu $47,62 \%$ melakukan penyimpanan obat pada wadah aslinya. Pada apotek waralaba sebagian besar yaitu $71,43 \%$ melakukan penyimpanan pada wadah asli. Penyimpanan di apotek perorangan dan waralaba sebagian besar yaitu $85,71 \%$ melakukan penyimpanann obat dipisah dengan produk lainnya.

Penyimpanan merupakan kegiatan atau usaha untuk melakukan pengelolaan obat di tempat penyimpanan, digolongkan berdasarkan bentuk bahan baku untuk menghindari dari hal-hal yang tidak diinginkan, penyusunan obat dilakukan dengan cara alphabetis untuk mempermudah pencarian dengan cepat, mempertahankan kualitas obat, serta aman dari pencurian (Hartini dan Sulasmono, 2007). Berdasarkan Peraturan Menteri Kesehatan No. 73 Tahun 2016, Semua Obat/bahan Obat harus disimpan pada kondisi yang sesuai sehingga terjamin keamanan dan stabilitasnya, tempat penyimpanan obat tidak dipergunakan untuk penyimpanan barang lainnya yang menyebabkan kontaminasi dan sistem penyimpanan dilakukan dengan memperhatikan bentuk sediaan dan kelas terapi Obat serta disusun secara alfabetis. Obat/bahan Obat harus disimpan dalam wadah asli dari pabrik. Dalam hal pengecualian atau darurat dimana isi dipindahkan pada wadah lain, maka harus dicegah terjadinya kontaminasi dan harus ditulis informasi yang jelas pada wadah baru.Pada hasil ini semua apotek perorangan dan waralaba telah mempunyai tempat khusus untuk penyimpanan obat.

Pengeluaran obat semua apotek perorangan maupun waralaba melakukan pengeluarkan obat menggunakan sistem FEFO (First Expire First Out) dan FIFO (First In First Out) dengan persentase $100 \%$. Metode FIFO (First in First Out), yaitu obat-obatan yang baru masuk diletakkan di belakang obat yang terdahulu, sedangkan metode FEFO (First Expired First Out) dengan cara menempatkan obat-obatan yang mempunyai ED (Expired Date) lebih lama diletakkan dibelakang obat-obatan yang mempunyai ED lebih pendek. Pemusnahan obat obat kadaluwarsa atau rusak harus dimusnahkan sesuai dengan jenis dan bentuk sediaan (Kemenkes RI, 2016). Pada apotek perorangan mayoritas melakukan pemusnahan obat sesuai dengan jenis dan bentuk sediaan sesuai dengan peraturan Peraturan Menteri Kesehatan No. 73 Tahun 2016 sebanyak 90,48\% dari 21 responden, sisanya mungkin tidak melakukannya sesuai peraturan atau bisa juga tidak melakukan pemusnahan. Pada apotek waralaba sebesar $100 \%$ dari 7 responden melakukan pemusnahan sesuai peraturan yang ditetapkan.

Pencatatan dilakukan pada setiap proses pengelolaan Sediaan Farmasi, Alat Kesehatan, dan Bahan Medis Habis Pakai meliputi pengadaan (surat pesanan, faktur), penyimpanan (kartu stock), penyerahan (nota atau struk penjualan) dan pencatatan lainnya disesuaikan dengan kebutuhan. Nota atau struk penjualan penting untuk pencatatan tiap proses penyerahan agar lebih memudahkan 
pelaporan penggunaan obat (Kemenkes RI, 2016). Dari 21 responden apotek perorangan hanya $47,62 \%$ yang melakukan penjualanan disertai nota atau struk pembayaran, dan pada apotek waralaba sebesar $100 \%$ yang melakukan penjualan disertai nota atau struk pembayaran. Pada dokumentasi penjualan apotek perorangan tidak selalu mencatat atau mendokumentasikan setiap transaksi penjualan, hal ini di buktikan dari hasil penelitian bahwa apotek perorangan yang melakukan dokumentasi penjualan hanya sebesar 95,24\% beda dengan apotek waralaba, semua apotek waralaba pada responden peneliti melakukan dokumentasi penjualan.

Pelaporan terdiri dari pelaporan internal dan eksternal. Pelaporan internal merupakan pelaporan yang digunakan untuk kebutuhan manajemen Apotek, meliputi keuangan, barang dan laporan lainnya. Pelaporan eksternal merupakan pelaporan yang dibuat untuk memenuhi kewajiban sesuai dengan ketentuan peraturan perundang-undangan meliputi pelaporan narkotika, psikotropika dan pelaporan lainnya (Kemenkes RI, 2016). Pada proses pelaporan apotek perorangan sebesar 90,48\% yang melakukan pencatatan pengeluaran narkotika dan psikotropika, hasil ini dimungkinkan karena beberapa apotek perorang tidak memiliki persedian obat psikotropika dan narkotika. Sedangkan pada apotek waralaba semunya melakukan pencatatan pengeluaran obat narkotika dan psikotropika dengan persentase sebesar $100 \%$. Untuk pelaporan penggunaan obat tidak semua apotek melakukan pelaporan obat atau sediaan farmasi, baik apotek perorangan maupun apotek waralaba. Hal ini dikarenakan sebagian besar apotek telah menggunakan Sistem Informasi Manajemen Apotek atau SIM Apotek sehingga untuk pelaporan sudah secara otomatis ada pada sistem tersebut. Sedangkan untuk pelaporan penggunaan narkotika dan psikotropika, apotek perorangan dan waralaba semunya melakukan pelaporan pengeluaran narkotika dan psikotropika.

Pengkajian resep yang meliputi persyaratan administratif, kesesuaian farmasetik dan pertimbangan klinis. Pengkajian resep dilaksanakan dengan tujuan untuk meminimalisir terjadinya medication error atau terjadinya kesalahan dalam pemberian Obat. Persyaratan administratif pelayanan farmasi klinik di apotek meliputi : nama, umur, jenis kelamin dan berat badan pasien, nama dokter, nomor Surat Izin Praktik (SIP), alamat, nomor telepon, paraf dan tanggal penulisan resep. Kesesuaian farmasetik meliputi bentuk dan kekuatan sediaan, stabilitas dan kompatibilitas sediaan. Pertimbangan klinis dalam pelayanan kefarmasian meliputi : indikasi, dosis dan aturan pemakaian obat, cara pemberian serta lama penggunaan obat, dupilkasi atau polifarmasi, alergi obat, efek samping, kontra indikasi dan interaksi obat (Kemenkes RI, 2016). Dari 21 apotek perorangan dan 7 apotek waralaba, semua apotek (100\%) melaksanakan skrining resep tentang persyaratan administratif. Pada pengkajian kesesuaiaan farmasetis, dari 21 apotek perorangan terdapat 17 $(80,95 \%)$ apotek melaksanakan pengkajian kesesuaian farmasetik secara keseluruhan, dan sisanya tidak melakukan pengkajian farmasetik secara menyeluruh. Sedangkan pada apotek waralaba menunjukan $5(71,43 \%)$ dari 7 apotek melaksanakan pengkajian kesesuaian farmasetik secara keseluruhan, serta $2(28,57 \%)$ apotek tidak melakukan pengkajian kesesuaian farmasetik tentang stabilitas dan kompatibilitas obat. Pada pengkajian pertimbangan klinis apotek perorangan yang melaksanakan pertimbangan klinis secara keseluruhan adalah 80,95\%, sedangkan di apotek waralaba sebesar $57,14 \%$. Hal tersebut dapat dikatakan bahwa pelayanan farmasi klinik dalam hal pertimbangan klinis di apotek perorangan dapat dikatakan baik dan di apotek waralaba dapat dikatakan cukup. Dengan begitu masih memungkinkan terjadinya medication error.

Penulisan resep obat harus ditulis dengan lengkap dan jelas, hal ini untuk menghindari adanya kesalahan apoteker dalam membaca dan memberikan obat kepada pasien. Jika terjadi keraguan dalam pembacaan resep maka sebaiknya apoteker berkonsultasi dengan dokter penulis resep (Kemenkes RI, 2016). Sebanyak 20 apotek perorangan $(95,24 \%)$ dari 21 apotek perorangan dan 6 apotek waralaba (85.71\% ) dari 7 apotek waralaba di Yogyakarta selalu melakukan konsultasi dengan dokter penulis resep apabila terdapat keraguan dalam pembacaan resep obat. Sebanyak 20 
apotek perorangan $(95,24 \%)$ dari 21 apotek perorangan dan $7(100 \%)$ apotek waralaba di Kota Yogyakarta selalu melakukan pengecekan kesesuaian obat dan etiket dengan resep sebelum diserahkan kepada pasien. Menurut Permenkes Nomor 73 tahun 2016 dijelaskan bahwa etiket harus jelas dan dapat dibaca karena ketidakjelasan dalam penulisan etiket dapat menyebabkan kejadian medication error karena pasien salah dalam membaca etiket/mengartikan tulisan dalam etiket.

Dari 21 apotek perorangan di wilayah Kota Yogyakarta 17 apotek (80,95\%) melibatkan apotekernya dalam penyerahan obat kepada pasien dan 4 apotek $(19,05 \%)$ tidak melibatkan apotekernya dalam penyerahan obat kepada pasien. Sedangkan di apotek waralaba dari 7 apotek terdapat 5 apotek $(71,43 \%)$ yang selalu melibatkan apotekernya dalam penyerahan obat. Pada pasal 7 tentang kode etik apoteker telah disebutkan bahwa apoteker harus menjadi sumber informasi sesuai dengan profesinya. Sehingga lebih baik jika penyerahan obat di apotek dilakukan langsung oleh apoteker agar apoteker dapat memberikan informasi yang jelas mengenai obat, apoteker juga dapat melakukan tugas sebagaimana mestinya dan juga untuk mengurangi terjadinya medication error (ISFI, 2009). Pemberian informasi obat kepada pasien meliputi cara pemakaian, cara penyimpanan, jangka waktu pengobatan, makan minum serta aktifitas yang harus dihindari oleh pasien. Dari 21 apotek perorangan di wilayah Kota Yogyakarta hanya 15 apotek $(71,43 \%)$ yang memberikan informasi secara menyeluruh kepada pasien dan sisanya hanya memberikan sebagian dari informasi tersebut. Sedangkan pada apotek waralaba dari 7 apotek terdapat 6 apotek (85,71\%) yang memberikan informasi secara lengkap dan hanya 1 apotek $(14,29 \%)$ yang tidak memberikan informasi secara lengkap.

Apoteker melakukan konseling kepada keluarga pasien/pasien yang termasuk dalam kriteria pasien yang perlu diberi konseling untuk meningkatkan pengetahuan, pemahaman, kesadaran dan kepatuhan sehingga terjadi perubahan perilaku dalam penggunaan obat dan menyelesaikan masalah yang dihadapi oleh pasien. Kriteria pasien/keluarga pasien yang perlu diberi konseling antara lain : Pasien kondisi khusus (pediatri, geriatri, gangguan fungsi hati dan/atau ginjal, ibu hamil dan menyusui), Pasien dengan terapi jangka panjang/penyakit kronis (misalnya: TB, DM, AIDS, epilepsi), Pasien yang menggunakan Obat dengan instruksi khusus (penggunaan kortikosteroid dengan tappering down/off), Pasien yang menggunakan Obat dengan indeks terapi sempit (digoksin, fenitoin, teofilin), Pasien dengan polifarmasi; pasien menerima beberapa Obat untuk indikasi penyakit yang sama. dan Pasien dengan tingkat kepatuhan rendah (Kemenkes RI, 2016). Dari 21 apotek perorangan di Kota Yogyakarta 15 apotek (71,43\%) diantaranya telah melakukan konseling kepada pasienn dan 6 apotek $(28,57 \%)$ diantaranya tidak melakukan konseling kepada pasien. Di apotek waralaba wilayah Kota Yogyakarta 6 dari 7 apotek (85,71\%) telah melakukan konseling kepada pasien sedangkan sisanya tidak melakukan konseling kepada pasien.

Pengajuan tiga pertanyaan atau Three Prime Question pada saat melakukan konseling bertujuan untuk mencegah pemberian informasi yang bertentangan dengan informasi yang telah disampaikan oleh dokter sehingga pasien tidak akan meragukan kompetensi dokter atau apoteker dan juga untuk menggali informasi mengenai pasien. Dari 21 apotek hanya 8 apotek $(38,10 \%)$ yang melakukan Three Prime Question secara keseluruhan sedangkan 7 apotek waralaba (100\%) melakukan Three Prime Question. Penderita penyakit tertentu seperti cardiovaskuler, diabetes, asma, TBC dan penyakit kronis lainnya seperti yang telah ditetapkan pada Permenkes No 73 Tahun 2016 bahwa penderita penyakit tertentu atau pasien dengan kondisi khusus seharusnya diberikan konseling secara berkelanjutan guna meningkatkan pengetahuan, pemahaman, kesadaran, kepatuhan pasien dan menghindari kebosanan saat pasien diharuskan mengkonsumsi obat dalam jangka panjang sehingga terjadi perubahan perilaku dalam penggunaan obat dan dapat menyelesaikan masalah yang dihadapi pasien. Dari 21 apotek hanya $8(38,10 \%)$ apotek yang menyediakan jam konseling secara berkelanjutan kepada pasien tertentu dan sisanya tidak menyediakan jam konseling secara berkelanjutan kepada pasien tertentu. Sedangkan di apotek 
waralaba dari 7 apotek hanya $3(42,86 \%)$ apotek yang menyediakan jam konseling secara berkelanjutan kepada pasien tertentu. Dari 21 apotek hanya 8 apotek $(38,10 \%)$ yang melakukan tindak lanjut terapi melalui komunikasi atau kunjungan kepada pasien dan 13 apotek $(61,90 \%)$ diantaranya tidak melakukan tindak lanjut terapi melalui komunikasi atau kunjungan kepada pasien, sedangkan di apotek waralaba dari 7 apotek 3 apotek $(42,86 \%)$ telah melakukan tindak lanjut terapi melalui komunikasi atau kunjungan kepada pasien. Tujuan dari melakukan tindak lanjut terapi melalui komunikasi atau kunjungan yaitu untuk memastikan pasien mendapatkan terapi yang aman dan efektif dan untuk mengontrol kepatuhan pasien dalam penggunaan obat (Kemenkes RI, 2016).

Pelayanan informasi obat melalui brosur, poster atau penyuluhan dapat memberikan informasi dan edukasi kepada pasien sehingga pasien akan lebih mendapatkan informasi tentang obat dengan lebih jelas. Dari 21 apotek perorangan terdapat 16 apotek (76,19\%) telah melakukan pelayanan informasi obat misalnya melalui komunikasi telepon dengan pasien atau mengunjungi pasien dan sisanya tidak melakukan hal tersebut. Sedangkan di apotek waralaba dari 7 apotek terdapat 6 apotek $(85,71 \%)$ telah melakukan pelayanan informasi obat misalnya melalui brosur, poster atau penyuluhan.

Hasil ini sesuai dengan penelitiannya sebelumnya yang dilakukan oleh Monica Arum Sukmajati yang menyebutkan bahwa Kepmenkes RI No. 1027/MENKES/SK/IX/2004 belum dilaksanakan secara menyeluruh oleh apotek apotek Kota Yogyakarta karena masih terdapat persentase pelaksanaan dibawah 50\% pada tiga parameter utama Kepmenkes RI No. 1027/MENKES/SK/IX/2004. Penelitian lainnya yang dilakukan oleh Atmini tentang Analisa Aplikasi Standar Pelayanan Kefarmasian di Apotek Kota Yogyakarta pada tahun 2011 menyatakan bahwa secara keseluruhan menunjukkan bahwa standar pelayanan kefarmasian di apotek kota Yogyakarta belum terlaksana dengan baik. Diperoleh skor total standar pelayanan kefarmasian di apotek kota Yogyakarta, menurut masing-masing responden sebagai berikut menurut apoteker 21\% (baik), 79\% (cukup); menurut karyawan 21\% (baik), 75\% (cukup), 4\% (kurang); sedangkan menurut pasien 38\% (baik), 42\% (cukup), 20\% (kurang) (Atmini, 2011).

Dari hasil implementasi standar pelayanan kefarmasian apotek Peroranganan dan waralaba dilakukan uji Normalitas Shapiro-Wilk untuk mengetahui data terdistribusi normal atau tidak, untuk melihat ada tidaknya perbedaan implementasi standar pelayanan kefarmasian di apotek Peroranganan dan apotek waralaba dilajutkan uji Independen Sampel Test jika data terdistribusi normal atau uji Mann-Whitney jika data tidak terdistribusi normal. Data dikatakan terdistribusi norma jika nilai Sig. $>0,05$. Setelah dilakukan uji normalitas hasil yang didapat tidak terdistribusi normal karena nilai Sig. 0,01<0,05. Karena data tidak terdistribusi normal maka dilakukan uji Mann-Whitney. Pada uji Mann-Whitney diketahui bahwa nilai Asymp. Sig. (2-talled) sebesar 0.103 $>0.005$, maka dapat disimpulkan bahwa tidak ada perbedaan pada implementasi standar pelayanan kefarmasian di apotek Peroranganan dan apotek waralaba di Kota Yogyakarta.

\section{KESIMPULAN}

1. Apotek Peroranganan dan apotek waralaba di Kota Yogyakarta dalam mengimplementasikan Standar Pelayanan Kefarmasian telah sesuai dengan peraturan Menteri Kesehatan RI Nomor 73 Tahun 2016 tentang Standar Pelayanan Kefarmasian Di Apotek, Persentase implementasi standar pelayanan kefarmasian di apotek Peroranganan sebesar 76,34 \% dan diapotek waralaba sebesar $82,97 \%$.

2. Menurut hasil uji SPSS dengan metode uji Mann Whitney dikatakan bahwa tidak terdapat perbedaan yang signifikan antara pelayanan kefarmasian di apotek Peroranganan dan waralaba di wilayah Kota Yogyakarta karena dari hasil uji Mann Whitney menunjukan nilai sig. (2-tailed) $0.103>0,05$. 


\section{DAFTAR PUSTAKA}

Arikunto, S. 2002. Prosedur Penelitian Suatu Pendekatan Praktek. PT. Rineka Cipta. Jakarta.

Atmini, Kuswardani Dwi., Ibnu Gholib Gandjar,. Ahmad Purnomo. 2011. Analisa Aplikasi Standar Pelayanan Kefarmasian di Apotek Kota Yogyakarta. Fakultas Farmasi Universitas Gadjah Mada. Yogyakarta.

Dinkes Yogyakarta, 2015. Profli Kesehatan Kota Yogyakarta. Yogyakarta.

Galih, 2007 “Apotek; bisnis basah di samudra biru”, Pharmacy Business; an overview of pharmacy related and healthcare industry

Handayani RS, Raharni, Retno G. 2009. "Persepsi Konsumen Apotek Terhadap Pelayanan Apotek Di Tiga Kota Di Indonesia”. Makara Kesehatan. Volume 13(1). Jakarta.

Ikatan Sarjana Farmasi Indonesia. 2009. Keputusan Kongres Nasional XVIII/2009 Ikatan Sarjana Farmasi Indonesia Nomor 006/KONGRES XVIII/ISFI/2009 Tentang Kode Etik Apoteker Indonesia. Jakarta.

Istiqomah, Fatimah Nur, 2012, Evaluasi Implementasi Standar Pelayanan Kefarmasian Oleh Apoteker, Jurnal Manajemen dan Pelayanan Farmasi (JMPF)

Kemenkes RI, 2016, Peraturan Mentri Kesehatan Republik Indonesia Nomor 73 Tahun 2016 Tentang Standar Pelayanan Kefarmasian di Apotek, Jakarta.

Kemenkes RI, 2017, Peraturan Mentri Kesehatan Republik Indonesia Nomor 9 Tahun 2017 tentang Apotek, Jakarta.

Kota, Nur Putri, 2012, Apotek Mandiri VS Apotek Waralaba, https://www.kompasiana.com/nurputrikoto/551022a6813311aa39bc6051/apotek-mandirivs-apotek-waralaba, diakses pada 14 Agustus 2019

Sugiyono. 2013. Metode Penelitian Pendidikan Pendekatan Kuantitatif, Kualitatif, dan R\&D. Bandung: Alfabeta

Sukmajati, Monica arum., 2007. "Pelaksanaan Standar Pelayanan Kefarmasian Di Apotek Berdasarkan Kepmenkes RI No.922/Menkes/Per/X/1993 Di Kota Yogyakarta". Skripsi. Falkutas Farmasi. Universitas Sanata Dharma. 